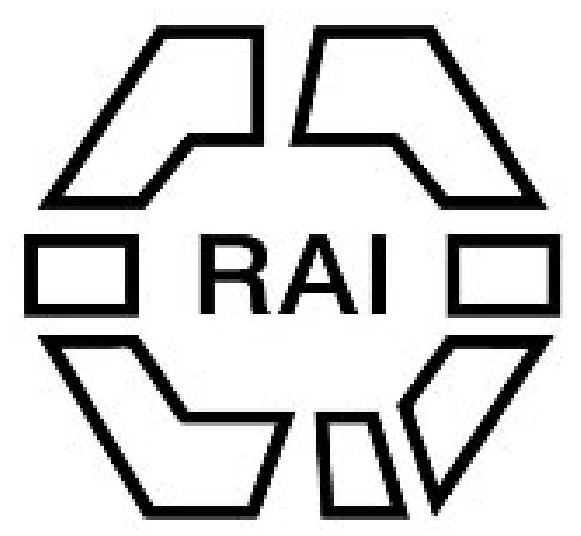

Some Remarks on Totemism as Applied to Australian Tribes

Author(s): Baldwin Spencer and F. J. Gillen

Source: The Tournal of the Anthropological Institute of Great Britain and Ireland, Vol. 28, No. 3/4 (1899), pp. 275-280

Published by: Royal Anthropological Institute of Great Britain and Ireland

Stable URL: http://www.jstor.org/stable/2842877

Accessed: 16/06/2014 09:39

Your use of the JSTOR archive indicates your acceptance of the Terms \& Conditions of Use, available at http://www.jstor.org/page/info/about/policies/terms.jsp

JSTOR is a not-for-profit service that helps scholars, researchers, and students discover, use, and build upon a wide range of content in a trusted digital archive. We use information technology and tools to increase productivity and facilitate new forms of scholarship. For more information about JSTOR, please contact support@jstor.org.

Royal Anthropological Institute of Great Britain and Ireland is collaborating with JSTOR to digitize, preserve and extend access to The Journal of the Anthropological Institute of Great Britain and Ireland. 


\section{SOME REMARKS ON TOTEMISM AS APPLIED TO AUSTRALIAN TRIBES. ${ }^{1}$}

By Professoli Baldwin Spencer, M.A., and F. J. Gillen.

IN our work upon The Native Tribes of Central Australia, we have described in detail certain features concerned with the totemic system of the Arunta, Ilpirra, and other tribes, and at the suggestion of $\mathrm{Mr}$. Frazer, to whose work and personal assistance we are deeply indebted, we venture to put forward certain tentative ideas with regard to the possible meaning and origin of totemism as applied to our Australian tribes-ideas also which have independently suggested themselves to Mr. Frazer.

Totemism, to use Mr. Frazer's terms, has both a religious and a social aspect, and it would appear that in the Arunta and other Central Australian tribes, the former, which we believe that Mr. Frazer would now prefer to designate as magical rather than religious, is predominant, whilst in the coastal tribes such as those dealt with by Messrs. Fison, Howitt, and other workers, the social is at the present day the predominant feature, the religious or magical being but slightly marked. In the case of other tribes, such as the Urabunna and Dieri, the area occupied by which lies between that of the Central and Eastern coastal tribes, the social aspect is strongly marked, but at the same time the religious is also clearly indicated.

In all tribes, so far as is known, there is supposed to exist some special connection between the material object and the members of the group of individuals who bear its name as their totemic name, while in addition to this, in certain tribes, the social aspect is revealed by the fact that members of one or more particular totemic groups are restricted in their marital relations to the members of other particular totemic groups.

In addition to these totemic groups we find in all Australian tribes, with very rare exceptions, that there are other and larger social divisions which are variously designated as class and sub-class, or phratry and sub-phratry, and that primarily each tribe is divided, quite apart from the totemic groups, into two exogamic moieties.

In the majority of Australian tribes yet studied, each exogamous moiety has been found to include a certain number of totemic groups, and the latter have, in consequence of this, been described as exogamic. If, for example, we take the Dieri or Urabunna tribe, we find that there are two moieties, one called Kirarawa and the other Matthuri, and that in the former are included such totemic groups as carpet snake, lizard, crow, and in the latter others, such as duck, dingo, emu.

1 The substance of these remarks was delivered by Professor Baldwin Spencer at the meeting of the Anthropological Institute held 14th December, 1898. 
Now, as a Kirarawa man must marry a Matthuri woman, it follows that a man of one totem can only marry a woman of another, and thus the idea of the close association of totemism and exogamy has been brought about.

In the Arunta and other tribes we find a very different state of affairs, and it would appear to be quite possible that the original aspect of the totem is simply a religious or magical one, and that the social aspect has been, as it were, tacked on at a later period. In these tribes we find (1) a division into exogamic moieties and (2) a division into totemic groups which are not exogamic, that is, each of the exogamic moieties includes totemic groups of the same designation. Each original moiety has been divided into two, so that there are now four divisions in the tribe, two of which represent one moiety and the remaining two the other. This may be represented in the following diagram :-

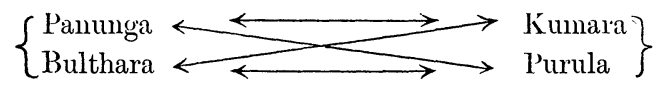

Here Panunga and Bulthara represent one moiety and Kumara and P'urula the other. The crossed arrows represent the marriage obligation, the horizontal arows indicate the division into which the child passes. Thus if a Panunga man marries, as he must, a Purula woman, their children are Bulthara; if a Purula man marries a Panunga woman their children are Kumara, and so on. Now, each of these four divisions may include members of one totemic group, so that, for example, a Panunga man of the emu totem may marry a woman of the emu totem provided she belong to the Purula. ${ }^{1}$

We thus see that in these tribes the totemic groups are not exogamic; we have the same exogamic moieties as in the Dieri, Urabunna, and, indeed, nost Australian tribes, but each moiety contains totemic groups of the same designation.

If now we turn to the Aruuta tribe, which may be taken as representative of those in which the totemic groups are not exogamic, we tind an important series of traditions. They deal with the former existence of a state of affairs which is not only very suggestive, but, inasmuch as it differs from the system now in vogue, the traditions may, perhaps, be reasonably supposed to point back to a time when conditions were in reality very different from those which now obtain. It is, of course, quite open to question as to how much reliance is to be placed upon them. If they simply explained the origin of the present system out of, as it were, no system, then we might regard them as simply myths invented to account for the former, but when we find that they deal with a gradual development and with a former state of organisation and customs quite different from and in important respects at variance with the organisation and customs of the present day, we are probably right in regarding them as actually indicative of a time when these were

1 Full details with regard to this are given in The Native Tribes of Central Australia, cap. ii. In actual practice only half of the Purula women are eligible as wives to any particular Panunga man, but this does not affect the main point, which is, that a Panunga emu man nay marry a Purula eniu woman. 
different from those now in force. ${ }^{1}$ Summarising the traditions very briefly what we find is this :

(1) A time when men of one totem had marital relations normally with women of the same totem.

(2) A time when men and women of what are now exogamic groups had marital relations.

(:) A time when exogamic divisions were in force but different from those of the present day.

(4) A time when the present exogamic divisions were introduced.

It may also be noticed, in passing, that the introduction of changes is definitely ascribed to certain leading influential men who were the heads of powerful local groups.

For the present purpose the most important point to notice is the traditional existence of totems long before that of exogamic groups, and the fact that when the latter did arise, the totems were not affected by them; in other words totemism appears to be a primary and exogamy a secondary feature. At the present day in the Arunta tribe, in which each individual is regarded as the reincarnation of an ancestral spirit, the latter by entering the body of a woman belonging to a particular exogamic group may change his own group, but his totem never changes.

In the earliest times of which we find any tradition we meet with totemic groups, and the one important feature of all of these is that their numbers are ('harged with the duty of performing certain magical ceremonies called Intichiuma, the object of which is that of securing the multiplication of the particular object, the name of which is borne by the group as its totemic name. It would appear as if there were at all events a strong probability that this, amongst our Australian tribes, may be the primary function of a totemic group just as it is at the present day in the Arunta, Ilpirra, and certain Central Australian tribes. ${ }^{2}$

It may, perhaps, be objected to this, that in the case of these tribes we are dealing with abnormal ones in which the totems have a different signification from that which is borne by them in other tribes in which the totemic groups are exogamic. To this it may be replied that there is very clear evidence that the totemic groups in various other tribes, such as the Dieri, Urabunna, and others to the north-east of Lake Eyre, in which the totemic groups are exogamic, are charged with precisely the same duty, for in these, just as in the Arunta and Ilpirra, we meet with ceremonies which are clearly the exact equivalents of the Intichiuma ceremonies already described by us. ${ }^{2}$

At the present day a man may only eat sparingly of his own totem, but it would appear as if in earlier days there were no such restriction. We meet, for example, with traditions such as the following; groups of plum-tree men feeding regularly upon plums; wild-cat men are changed into plum-tree men and after that travel on feeding upon plums; a bandicoot woman changes a Hakea tree

1 A detailed account of these traditions is given, op. cit., cap. $\mathrm{x}$ and $\mathrm{xi}$.

= These ceremonies are described in detail op. cit., cap. vi p. 167. 
woman into a bandicoot, who then goes on feeding upon bandicoots; a wallaby man wishes to kill and eat a kangaroo, but before doing so he has to change himself into a kangaroo. Traditions such as these can only be regarded as pointing back to a time when a man actually had the right to eat his own totem, when, in fact, it was the normal thing for him to do so.

At the present day the native will not eat much of his own totem. On the other hand it must be remembered (1) that he not only has no objection to other people doing so, but will actually help them to secure it by means of magic; (2) that he claims, as is clearly seen at the close of the Intichiuma ceremony when the members of each totemic group partake of what can only be described as a totemic sacrament, the first right to his totem ; and (3) that he considers that to eat none of his totem would have just as evil effects as to eat too freely. It is essential for him to partake of the totem so as to identify himself closely with it, or else he would be unable to perform the ceremony, and the supply would vanish.

In former times apparently a man ate freely of his totem and had the first right to it. At the present day whilst the latter feature is retained the former has been changed, but it must be remembered that the one essential feature is the necessity of identifying himself closely with his totem, by, at some time or another, partaking of it. How the change was brought about which has led to the present condition it is difficult to say. Perhaps, though at best any explanation can merely take the form of a conjecture, the idea arose that too much eating of the totem would result in an estrangement between the individual and his totemic animal or plant which would prevent his adequately performing the ceremony essential for the increase of the totem. That changes in custom do arise is a matter of certainty, and it is equally certain that such changes are adopted on the initiative of one or more of the older and influential men who are heads of powerful local groups.

The hypothesis which is now suggested, and which has been advanced independently also by Mr. Frazer, is that in our Australian tribes the primary function of a totemic group is that of ensuring by magic means a supply of the object which gives its name to the totemic group, and that further, the relation between totemism and exogamy is merely a secondary feature.

In regard to the latter the traditions of the Arunta tribe point to a very definite introduction of an exogamic system long after the totemic groups were fully developed, and further, they point very clearly to the fact that the introduction was due to the deliberate action of certain ancestors. Our knowledge of the natives leads us to the opinion that it is quite possible that this really took place, and that the exogamic groups were deliberately introduced so as to regulate marital relations. By this we do not mean to imply that the regulations had anything whatever to do with the idea of what we term incest, or of any harm accruing from the union of individuals who were regarded as too nearly related. Such ideas could only arise after some system regulating marital relations had been introduced and as a result of this. The idea of incest, for example, is a perfectly 
arbitrary one: what we regard as a perfectly natural and normal union, an Australian native will regard in the light of what we call an incestuous union and vice versh. It can only be said that far back in the early history of mankind there was felt the need of some form of organisation, and that this gradually resulted in the development of exogamic groups.

If we presuppose a tribe with certain totemic but with no exogamic groupsa condition revealed to us in the early traditions of the Arunta tribe-then any division, such as apparently has taken place in all Australian tribes, into two exogamic moieties would result in (1) placing all the members of one totemic group in one of the two moieties, or (2) in each of the latter comprising indiscriminately the members of various totemic groups. As this division of the tribe came to regulate marriage-possibly it was introduced for this purpose-it would follow that in (1) as in perhaps the majority of Australian tribes, a man of one totem was obliged to marry a woman of another, while in (2) such was not of necessity the case. When once in the case of (1) this train of reasoning had been followed up for some time, then it is not perhaps difficult to imagine that it would lead finally to the restriction of men of one totem to women of another special totem. The social aspect of the totem would thus become emphasized, and it would appear as if the totemic groups were essentially exogamic in nature, whereas, in reality, there is no primary relationship between the totemic system and exogamy.

In conclusion a few words may be added with regard to the question of soul transference in connection with the totem. Dr. Tylor" says, "The difficulty in understanding the relation of a clan of men to a species of animals or plants is met by the transmigration of souls which bridges over the gap between the two, so that the men and the animals become united by kinship and mutual alliance: an ancestor having lineal descendants among men and sharks, or men and owls, is thus the founder of a totem family, which mere increase may convert into a totem clan, already provided with its animal name. By thus finding in the world-wide doctrine of soul-transference, an actual cause producing the two collateral lines of man and beast, which constitute the necessary framework of totemism, we seem to reach at least something analogous to its real cause." Dr. 'Tylor then adds, illustrating the point by a reference to the Arunta system, "But considering the variations found even between neighbouring tribes in the working of their ideas, it would be incautious to lay down as yet a hard and fast scheme of their origin and development."

In the Arunta and other tribes the myth invented to account for the existing relationship between a totem clan and the totem animal or plant is that the ancestors of the former were the transformations of certain of the latter. At the same time it must be remembered that there is no idea of any such thing as the placing of the soul of a member of the totem in the totemic animal or plant, and that the life of this is not held sacred on account of the possibility of its containing the soul or spirit part of a near relative. A man will tell you that his totem is "the same thing as himself," but though he will only kill and eat it on certain

1 "Remarks on Totemism," Journ. Anthrop. Inst., August.November, 1898, p. 147. 
special occasions, yet he will actually help a friend belonging to another totem to do so at any time.

Until we were more deeply conversant with the totemic system of the Arunta people, we were under the impression that in regard to the non-eating of the totem we were dealing with a state of affairs practically identical with the well-known often-quoted description of Grey. The two most striking facts which the native tells you with regard to his totem are (1) that the man regards his totem as the same thing as himself, and (2) that he will not kill and eat it, or only very sparingly and with reluctance. It was only at a later perior when we had gained more minute information with regard to the significance of the totem as revealed in the sacred ceremonies concerned with Intichiuma, that we came to see more clearly the relationship between the man and his totem, and to understand that, though he regards his totemic animal as being "the same thing as himself," and that he will only on rare occasions kill and eat it, yet this by no means implies that he regards it as possibly containing the soul or spirit part of himself or of a human relative. In other tribes in which the social organisation is the same as in the tribes studied by Grey, and in which also a man will tell you that he only kills and eats his totem with reluctance, and sparingly, we find the same significance attached to the totem as in the Arunta tribe, and we venture to think that there is not sufficient evidence in regard to Australian tribes to warrant the idea that, the totemic animal or plant is regarded as containing the soul or spirit part of an individual bearing the totemic name.

\section{Discussion.}

Professor TyLOR congratulated Professor Baldwin Speucer on the success with which he had carried his zoological training into the path of Anthropology. A zoologist, he remarked, is half an anthropologist from the beginning. Among the novel and important information which Professor Baldwin Spencer had brought back from his exploration, his account of the native totem-system had, even in anticipation of the publication of the Spencer and Gillen volume on The Nrtive Tribes of Central Australia, aroused lively interest among anthropologists. The interpretation of the Arunta totems as resulting from soul-transmission carried on through sacred objects is not only intelligible, but is perhaps the only clearly formulated scheme of totemism yet described, which is intelligille at every step on savage animistic principles. In this it differs remarkably from most other totemsystems such as that of the Algonquins of America, in which the relation of the man to the totem-animal of his clan is obscure, probably because most foreigners who have described it have failed to ascertain the spiritual connexion involverl. An important feature in the Arunta-totems is their agreement with Wilken's theory, which traces them to the doctrine of transmigration of souls. So remarkable a new element thrown into the midst of the older accounts in Australia, America, and other countries, should be a warning against the premature framing of theories as to the origin of totems by anthropologists, especially in the absence of full comparison of evidence as to the animistic ideas connected with them. 